Doc. Anka Mihajlov Prokopović, ${ }^{*}$ PhD,

ПРЕГЛЕДНИ НАУЧНИ РАД

10.5937/zrpfn0-23433

Assistant Professor, Communicology and Journalism Department,

Faculty of Philosophy, University of Niš

Doc. Marija Vujović, ${ }^{*}$ PhD,

Assistant Professor, Communicology and Journalism Department,

Faculty of Philosophy, University of Niš

UDK: 316.774:004.738.5]:34(4-672EU:497.11)

004.738 .5

Рад примљен: 01.10.2019.

Рад прихваћен: 06.12.2019.

\title{
MEDIA IN THE DIGITAL AGE: REGULATORY ASPECTS ${ }^{* *}$
}

\begin{abstract}
The huge impact of digital technology has led to reconsidering the concept of the media. In theory, there is a common agreement about the new concept of the media, offered by Karol Jakubowicz (2009), which includes new content forms, new creators of content, and new media activities. Starting from this conception of the media, the European regulatory framework redefines many earlier solutions in its documents. A significant change is the "broadening" of the media concept that now includes Internet publications. On the other hand, editorial responsibility is a necessary condition for the website to be considered as a medium, and this requirement is defined in European media policy documents. The phenomena created as a result of the new digital environment pose significant challenges for media regulation. The Internet has enabled the direct participation of citizens who set up online content using new distribution channels; among other things, it leads to weakening the boundaries between the public and the private sphere. New intermediaries are entering the media sphere, such as Internet browsers and Internet content aggregators, which perform some media functions and functions similar to the media. The paper analyzes the solutions offered by European media regulations and Serbian legislation in this field.
\end{abstract}

Keywords: media regulation, digital media, Internet.

\footnotetext{
*anka.mihajlov.prokopovic@filfak.ni.ac.rs

*marija.vujovic@filfak.ni.ac.rs

** This paper was presented at the International Scientific Conference "Law and Multidisciplinarity", which was held at the Faculty of Law, University of Niš, on 12-13 April 2019.
} 


\section{Introduction}

Rapid and extensive development of digital technology has led to the rethinking of the media concept. Even before digital technology, the impact of technology on the media was substantial. All media were once new, and the academic and professional public discussed about the possible impact the new technologies would have on media sphere. Changes caused by new technology have also brought about changes in society: electronic media have increased mass audiences and led to an increase in media power. "Media play a crucial role in all modern societies" (Lorimer, 1998: 64). This was noticed very early in the past; in the $18^{\text {th }}$ century, the media were considered the fourth class (the first three classes were: church, landowners and bourgeoisie). The media often inform the public by providing analysis, while various groups and individuals "compete to interpret the real meaning of events" (Curran, 1990, in Lorimer, 1998: 64).

However, the new media that are emerging thanks to digital technology are making a dramatic change: all content can be represented in the same digital code, on the same device. Traditional media are changing with the emergence of new media formats and they can present their content on digital platforms). There is an active audience that posts blogs, tweets, records videos, and reports on disasters. Participatory journalism is born, where ordinary citizens act as journalists from the standpoint of witnesses of certain events, while professional journalists and professional media count on them in these situations. A new genre called live blog has been created, in which journalists and amateurs cover an ongoing event. Social media, Twitter above all, are becoming significant journalistic sources. Alfred Hermida, a Canadian author, professor and a former journalist and editor who launched the online edition of the BBC (1997), has coined the term ambient journalism which refers to listening to what the Twitter community has to say (Hermida, 2014: 360-361). Worldwide, traditional media (newspapers, radio, television) have had online editions for over a quarter of a century. Live streaming and podcast have changed the nature of traditional radio and enabled the renaissance of this medium. On-demand television has changed the way we choose television content. Online-only media are emerging, providing a possibility for new media pluralism.

\section{Theoretical approach}

This paper embraces the new media concept offered by Karol Jakubowicz (2009), which entails new content forms, new content creators, and new activities. Jakubowicz proposes that, thanks to the same digital code, all traditional media can become new, that citizen journalism is emerging in the digital environment, and that content aggregators and search engines are entering the digital media 
sphere (Jakubowicz, 2009: 19-26). We will see later that elements of this definition have become part of the European media policy documents.

Snježana Milivojević also writes about conceptual change and new understanding of the media (2017: 159-167). Changes were made on several levels. Citizens have become participants in communication whose activities are not subject to any institutional approval. Moreover, due to the technological capabilities provided by the Internet, citizens can interact with public office holders. This is how power relations change and a new form of democracy emerges, which theorist John Keane calls monitory democracy (Keane, 2011, in Milivojević, 2017: 162). Digital intermediaries have been created; these are search engines and social media platforms, which provide access to a wide variety of digital content. Milivojević believes that some of the most important features of new media are: convergence, simultaneity, mobility and interaction. Convergence is a vital process where, thanks to digital coding, all content can be displayed in all Internet-based media. The simultaneity of new media is a feature that describes the process in which information is transmitted at the moment it occurs, that is, a situation in which "media time (broadcasting) has accelerated to that point that it is almost the same as real-time" (Milivojević, 2017: 164). The mobility of new media has created an environment where the user decides where and when to start the communication flow. In the world of new media, interaction is a feature that implies media participation, that is, voluntary participation in public communication and without restrictions usually imposed by traditional media (Milivojević, 2017: 165-166).

\section{Regulation and the New Media: Challenges}

In his book called Mass Communications, the influential media theorist Rowland Lorimer noted that the biggest challenge for legislators and media policy makers is how to ensure that as many people as possible benefit from technological advances (Lorimer, 1998: 206). According to the sociologist Manuel Castells, who introduced the concept of mass self-communication, mass communications could now be renamed Mass Self-communications. These are the new online communication practices, such as individual production and choice/selection of content, distribution and reception of content practiced by a large number of Internet users, where the content, although individually produced or chosen, potentially reaches many users (Kastels, 2014: 92-101).

Public policies face major challenges imposed by the new digital media. When writing about this topic, media theorist Snježana Milivojević emphasizes the need for the Internet to remain a creative, innovative and deregulated place without state intervention, to remain what Ithiel de Sola Pool, previously speaking about 
mass media, called "technologies of freedom". However, with the rise of hatefilled websites and the promotion of violence, the protection of human rights is becoming a necessity in the digital sphere as well. Therefore, like many others, Milivojević wonders: "how can we protect human rights but not endanger the freedom of speech?" (Milivojević, 2017: 170). Recently, this issue has become even more relevant when Facebook was used to live-stream a terrorist attack carried out by Brenton Tarrant in New Zealand who broadcast the attack on his Facebook profile ${ }^{1}$.

Other areas are also subject to regulation, or at least the need for regulation is indicated. Such is the case with the right to personal data protection and internet privacy. Given the power of the internet companies such as Google, Microsoft and Facebook, citizens expect the state to protect their personal data from sale or misuse. There is a recent example of such abuse: Cambridge Analytica Ltd. illegally used the personal data of 50 million Facebook users to create voter profiles for Trump's 2016 presidential campaign².

The General Data Protection Regulation (GDPR) 2016/679, which was adopted by the the European Union in 2016 and entered into force in May 2018, replaced the former Data Protection Directive 95/46/EC which had provided guidance to EU member states for 23 years. In Serbia, the GDPR should be respected and observed by companies when processing personal data if they offer their goods or services to natural persons from the European Union. In Serbia, there is the Personal Data Protection Act adopted in November 2018. Rodoljub Šabić, then Commissioner for Information of Public Importance and Personal Data Protection, and the non-governmental organization Share Foundation suggested that this legislative act is merely a 'copy' of the General Data Protection Regulation (GDPR) adopted by the European Union. They claimed that "this law is a literal translation of the GDPR; thus, formal compliance with EU regulations is at the highest level; however, the law implementation in Serbia is questionable"3.

Given that most Internet users do not have enough knowledge about the applications they use, Vladan Joler of Share Lab defines this as soft colonization. He says that "Facebook has ceased to be merely an interactive digital scrapbook

1 Politika (2019). Ko je terorista sa Novog Zelanda? (Who is the New Zealand terrorist?). Politika, 15.3.2019; http://www.politika.rs/sr/clanak/425059/Ko-je-terorista-sa-NovogZelanda; Accessed 16.9.2019.

2 Stanojević, Z. (2018). Šta ti sve Fejsbuk moze? (What can Facebook do to you?) Vreme, 29.3.2018. https://www.vreme.com/cms/view.php?id=1587149 Accessed 16. 9. 2019.

3 SeecuritySee (2018). Usvojen Zakon o zaštiti podataka o ličnosti bez predloženih korekcija (The Personal Data Protection Act adopted without proposed corrections), 10.11.2018. Accessed 16. 9. 2019. https://www.securitysee.com/2018/11/usvojen-zakon-o-zastitipodataka-o-licnosti-bez-predlozenih-korekcija/ 
a long time ago. User tracking, data collection and analyzis is Facebook's main business model, as well as Google's"'.

Milivojević points out that the new media regulation is increasingly content-related while it is less rigorous with regard to institutions regulation (which was a typical feature of traditional media) (Milivojević, 2017: 170). This is necessary in order for the internet content to be subject to such regulations.

Privacy protection as one of the journalism standards has become highly questionable. In the digital world, people voluntarily relinquish their privacy (Milivojević, 2017: 172). Furthermore, they also relinquish their children's privacy (by posting pictures and videos of their underage children on social media). A recent example is the case of the daughter of the well-known American actress Gwyneth Paltrow, who criticized her mother for posting a photo without the girl's permission ${ }^{5}$.

\section{European digital media policy}

Since the 1980s, binary opposition has been present in European media policy: on the one hand, there is the market and, on the other hand, there is culture and pluralism (Milutinović, 2018: 109). This binary opposition was caused by the dominance of the American cultural industry in the European market, to which the European Community responded by adopting a joint strategy in order to increase competitiveness.

Europe has fought for the principle of "cultural exception", which allows it to set mandatory quotas and maintain a system of subsidies for the public service media. During the debates that took place at the World Trade Organization, the European Union sought to ensure that all digital media fall within the category of audio-visual services. The objective of the European Union is to maintain "it's limited liberalization commitments in these fields, and to keep implementing its programs in the audiovisual industry through bilateral trade or culture agreements" (Donders, Loisen \& Pauwels, 2014: 4-5). This view is explained in the Digital Agenda for Europe and the Audiovisual Media Services (AVMS) Directive" (Milutinović, 2018: 111).

The ideas of the European media policy on the limited movement of media products are difficult to apply in a digital environment where media content

4 Stanojević, Z. (2018). Šta ti sve Fejsbuk moze? Vreme. 29.3.2018. https://www.vreme. com/cms/view.php?id=1587149 Accessed 16. 9. 2019.

5 B92.net (2019). Mama, nije trebalo to da radiš bez mog pristanka (Mum, you should not have done it without my consent), 31.3.2019. https://www.b92.net/zivot/vesti. php? yyyy=2019\&mm=03\&dd=31\&nav_id=1523863 Accessed 16. 9. 2019. 
constantly flows and is globally available. This policy is disrupted by the interests of "the first-tier global media firms" (Herman \& Mekčesni, 2004: 79). Social media companies based in the US have more and more power in the media world and they are only partially regulated. Their goal is profit, not the public interest (COMMIT, 2018, in Milutinović, 2018: 117). Media pluralism becomes less important.

With regard to this issue, in the opinion of the European Federation of Journalists, the European Union has failed to protect the most important values of European democracy: pluralism and the public interest (Milutinović, 2018: 118). One of the solutions that deviates from European standards to the largest extent is the issue of electronic communication confidentiality. The Mass Surveillance Act, which was enacted in the UK in November 2016, is particularly striking when it comes to the above issue. Communication privacy of the Internet users is at risk, since this legislative act allows security services to monitor private communications even without obtaining a court order. Furthermore, criminal liability can be imposed on anyone who discloses facts based on "information leaks, which practically means that journalists, reporters and their sources can be accused of espionage and betrayal even though the published information is in the public interest and does no harm to the democratic order" (Milutinović, 2018: 119).

Restrictions on media freedom and threats to journalists' rights in the name of higher goals (most frequently- the fight against terrorism) exist not only in the UK but also in other European countries (Milutinović, 2018:120). In her paper, Milutinović concludes that European media policy suffers from a lack of consistency, which is manifested in the following facts: "There is no competent authority responsible for media policy at the European Union level; there is no constitution or an umbrella law which all European systems would be required to comply with; there is no uniquely articulated public interest recognized by the actors in this policy" (Milutinović, 2018: 124). The global economy has also influenced European values in the media sphere. "Paradigm shift has taken place: the principles and values that have evolved from the original matrix of the European democratic tradition over the centuries, and which became engrained in the policies governing communication processes in European communities in terms of standards have been sacrificed for the benefit of the non-public, that is, the economic, political, geostrategic and security interests" (Milutinović, 2018: 125).

The Audiovisual Media Services Directive (AVMD) ${ }^{6}$ is a very important document within the European digital media policy. It was adopted in 2007, as an amend-

6 Directive 2010/13/EU of the European Parliament and of the Council of 10 March 2010 on the coordination of certain provisions laid down by law, regulation or administrative 
ment to the previously adopted Television without Frontiers Directive (1989), which at the time of its adoption met the needs of the joint European media space. These needs were expressed through specific requests for free broadcasting of European television programs within the internal market, as well as through the desire to ensure the protection of European television programs by means of broadcasting quotas. The 1989 Directive required TV channels to reserve half of their program for European contents. Broadcasters also had to reserve ten percent of their program for contents created by independant European producers. Almost two decades later, this Directive was amended to accommodate the major changes introduced by the Internet to the television broadcasting industry, and then it got its new name (Mihajlov Prokopović, 2016: 55-56). Former broadcasters have become audio-visual service providers. "Digital technology has enabled television on-demand, and this document defines two types of services: linear audio-visual media service (television broadcasting) and nonlinear audio-visual media service (on-demand services) which programme users can watch at their own convenience. This Directive is based on the principles of technological neutrality and graduated regulation. The principle of technological neutrality means that all audio-visual services are treated in the same way regardless of the technology platform they use - television, internet or mobile phones. Graduated regulation involves the application of different levels of regulation, depending on the impact of different types of audio-visual services. The rules are more lenient when it comes to non-linear services because their impact is smaller due to the way they are used. This applies to the advertising policies and to the protection of minors" (Mihajlov Prokopović, 2016: 56).

In the new era of digital media, editorial control and the purpose of media have become the main criteria for distinguishing between media and new forms of communication practice. This is regulated by the Recommendation CM/Rec(2011)7 of the Committee of Ministers to member states on a new notion of media, adopted in 2011.

\section{Media sphere and regulations in the field of online media in Serbia}

From the media perspective but also from a broader social perspective, the situation in the field of digital technology in Serbia is characterized by the growth of the Internet, the fact that almost all young people have their profiles on social networks, and the emergence and development of the digital media sphere. The latest data show that $80.1 \%$ of households in Serbia have the Internet (Statistical

action in Member States concerning the provision of audiovisual media services (Audiovisual Media Services Directive). Avaliable in English at: https://eur-lex.europa.eu/legal-content/ EN/ALL/?uri=CELEX:32010L0013 (Accessed: 14.9.2019). 
Office of the Republic of Serbia, 2019: 12). Social networking profiles, Facebook and Twitter, account for $70.1 \%$ of the internet population (Statistical Office of the Republic of Serbia, 2019: 23-24). Only a small percentage of young people between the age of 16 and 24 do not have social media profiles; $96.4 \%$ of young people have social media pages (Statistical Office of the Republic of Serbia, 2018: 26). In Serbia, YouTube has the largest number of users ( 3.5 million users), followed by Facebook (3.3 million users) and Instagram (2.2 million users) (Direct Media United Solutions, 2019) ${ }^{7}$.

The number of online media in Serbia is increasing year by year; in 2018, there were 736 of them (IREX, 2019: 104). "Serbia has an established digital media sphere that is a growing media sector, which is very important when it comes to providing information to the public" (Mihajlov Prokopović \& Jevtović, 2017: 145). ${ }^{8}$

$B 92$ was the first to launch its online edition in Serbia in 1995, thanks to the desire for the freedom of speech, and after the closure of Radio B92 ${ }^{9}$. Other media soon followed suit: Politika (1997), Danas (1998), RTS (1999), Vreme (2000), and Blic (2003) (Mihajlov Prokopović, 2016: 199-200). Today, even those traditional media that were not digitally superior in the beginning, such as the weekly Vreme and the daily Danas, are introducing new media formats. For example, Danas has a Facebook interview, while Vreme has recently launched Vugl, an online media aimed at young users. Blic is the most visited web site, and its strategy is "digital first".

In digital environment, media brands are weakening as many new online-only based media have emerged. In spite of that trend, online editions of traditional media are still the most widely read both worldwide and in Serbia. In Serbia, these are: Blic (2.5 million visitors), Kurir (2.1 million visitors), and $B 92$ (2 million visitors) (IREX, 2018: 116). The problem with the newly established online media is that the content they present may be false. So, for example, high school students from the Macedonian city of Veles launched around 140 English-language websites that published fake news ahead of the 2016 US presidential election that they believed would be read by Trump voters. Since they had a huge number of visits, they made a lot of money. Eventually, though, they were discovered. Their motive was purely financial in nature - they wanted to make money. They

7 Direct Media United Solutions (2019). Media trends 2019. Available at https://directmedia. biz/wp-content/uploads/pdf/Media_Trends_2019.pdf Accessed 29.9.2019.

8 The paper elaborates on the indicators that confirm the emergence and growth of the digital media sphere.

9 Radio and television B92 no longer exists. Radio B92 first changed its work concept and its name to Play (radio) in 2015, and then B92 Television changed its concept and name to O2TV in 2017. At the time of writing this article, there is only B92 web portal (B92.net). 
were helped by the law of supply and demand; namely, the news about Trump was much less present in the mainstream media than that of Hillary Clinton (Warwick \& Lewis, 2017: 31, in Oxford Research Encyclopedia of Communication, 2018: 10). A 17-year-old who runs a site with four other people said: "I started the site for an easy way to make money. In Macedonia, the economy is very weak and teenagers are not allowed to work, so we need to find creative ways to make some money. I'm a musician but I can't afford music gear. Here in Macedonia, the revenue from a small website is enough to afford many things" (Silverman \& Alexander, 2016) ${ }^{10}$. Fake news is also a major challenge for regulation in the digital sphere.

The changes made to the traditional media due to the spread of the Internet in Serbia became the subject matter of regulation only after the adoption of the Public Information Act (2003), which stipulates in only one article that the term "public media" also includes "the Internet and other electronic issues of the media in question" (Article 11 PIA). Therefore, this law took into consideration the new media practice which had already included the online editions of traditional media for some time back then. Online media became the subject of consideration of the Strategy for the Development of the Public Information System in the Republic of Serbia until 2016, which equated them with traditional media when it came to the possibility of applying for a system of subsidies for the public service media (Mihajlov Prokopović, 2016: 194). "The Public Information and Media Act (PIMA), adopted in 2014, deals with the production of content on the Internet in Articles 29 through 31 PIMA. This Act recognized for the first time that the media also includes 'independent electronic publications (editorially driven websites or web portals)' if they are registered in the Media Register (Article 29 PIMA). Article 30, paragraph 2 of this Act states that media do not include 'internet platforms, such as internet forums, social media and other platforms that allow the free exchange of information, ideas and opinions among its members, or any other independent electronic publications, such as blogs, web presentations and similar electronic presentations, unless they are registered in the Media Register in accordance with this Act. This, in fact, guarantees freedom of speech on the Internet" (Mihajlov Prokopović, 2016: 195). If they want to gain media status together with all the rights and obligations that come with it, the website founders must register it in the Media Register.

The Electronic Media Act of the Republic of Serbia (EMA), adopted in 2014, regulates the field of audio-visual services, in many respects following the European

10 BuzzfeedNews (2016). How Teens in the Balkans Are Duping Trump Supporters With Fake News. BuzzfeedNews, November, 3, 2016; available at: https://www.buzzfeednews. com/article/craigsilverman/how-macedonia-became-a-global-hub-for-pro-trump-misinfo Accessed 29.9.2019. 
Directive on audiovisual services by applying the principles of technological neutrality and graduated regulation. The Act regulates all audio-visual services in the same way, regardless of the distribution method and the device through which the content is mediated (television, computer or mobile phone), which reflects the principle of technological neutrality. This Act also prescribes stricter rules for regulating linear broadcasting than it does for television on-demand, which is the example of the principle of graduated regulation. The Act regulates entirely new services, such as web television and internet radio, by prescribing their mandatory registration in the Media Register (Mihajlov Prokopović, 2016: 195-196).

\section{Journalistic self-regulation}

The radical changes that the Internet has made to journalistic practice have inevitably led to the rethinking of journalism ethics and standards, and the possibility of their consistent application in the new digital environment. In media theory, two sets of opinions have emerged. The first one claims that professional ethics and codes of conduct that applied in the offline world remain the same in the online world (Belsey and Chadwick, 1992, in Diaz-Campo \& Segado-Boj, 2015: 736). Another approach to this challenge is provided by those authors who talk about the big changes that the media world and journalism have experienced and continue to experience, and which are reflected in many formerly accepted solutions to ethical and professional dilemmas. "Interactivity, hypertextuality, the use of multimedia, and immediacy are some of the main features of digital journalism, and each of these, of course, raises its own new ethical issues" (Diaz-Campo \& Segado-Boj, 2015: 736). For example, citizen participation in the professional news making process is a complete novelty. Citizen journalists comment on news on media websites, become a source of information and collaborate in research, including writing online articles. How can we ensure that these amateur journalists first get to know and accept journalism ethics and standards? Some media provide education opportunities for amateur journalists before allowing them to work for them. Such is the case with the Belgian newspaper Het Belang van Limburg, which conducted training for the 80 citizens who were hired, after that training, to report on local topics for that newspaper (Hermida, 2011: 22).

There are other areas in which there is a growing need for new solutions or for reviewing the old ones. This is especially true when one considers the fact that the boundaries between the private sphere and the public sphere are continually dissolving, or when we talk about hate speech that could easily get transferred from social networks into journalistic discourse. In her article "Taking Responsi- 
bility: Legal and ethical issues in participatory journalism", Jane Singer lists and analyses the challenges of participatory journalism: defamation, hate speech, and intellectual property (Singer, 2011: 131-133). Ana Martinoli and contributors mention the most important ethical issues of online journalism: "evaluating sources for reliability, republishing existing content (from the standpoint of privacy and copyright), transparency and accountability (mistake correction, conflicts of interest), as well as finding a balance between commercial and public interests (covert advertising, sensitive content: violence, pornography, hate speech)" (Martinoli, Krivokapić, Perkov, Stojković, 2019: 54). All of this has led many authors to advocate for the establishment of new professional and ethical rules, or at least for the old ones to be reviewed. Regardless of these new regulation areas and issues, it is indisputable that "regulation must have the same importance and influence in the online and offline world" (Milivojević, 2017: 169).

In this area, self-regulation is a significant instrument, as was the case before the Internet. It allows journalists to write professional and ethical rules themselves. According to Mijatović, this is a great advantage for online journalism: "self-regulation appears to be a solution to increase online accountability while offering more flexibility than state regulation" (Mijatović, 2013:5, according to Diaz-Campo \& Segado-Boj, 2015: 737). An analysis of journalistic codes of ethics in 88 countries (including Serbia), which was conducted in 2015, reveals that only nine countries had sections dedicated to online journalism and journalists. Canada, the United Kingdom and Norway were the only countries which included these new journalism areas into their journalist codes of ethics (Diaz-Campo \& Segado-Boj, 2015: 735).

In Serbia, the Press Council was established as a self-regulatory body in 2009. Today, its jurisdiction is accepted by online media as well. In addition to the daily newspapers, magazines, local media and news agencies, the Press Council website also includes web portals (35 online media). These are online media that accept the jurisdiction of the Press Council. However, the Press Council can also make decisions in cases where the subjects do not recognize its jurisdiction because this body "has established a limited jurisdiction towards the media which did not accept its full jurisdiction. This makes it possible to file a complaint against any print media, news agency or news portal if it is believed that the Journalists' Code of Ethics has been violated" (Share fondacija, 2017: 50). Since the Journalists' Code of Ethics was adopted in 2006, at a time when the online sphere had just started being developed, it was later on necessary to adapt and supplement many provisions of the Journalists' Code of Ethics with the new solutions which would provide for addressing the problems arising 
in the digital media sphere. In 2016, the Press Council adopted, ${ }^{11}$ which follow the structure of the Journalists' Code of Ethics. Eight out of ten chapters in the Journalists' Code of Ethics have been adapted to include the online environment. More space was given to the areas referring to the citizen journalism content, the use of information from social media and respect for the copyrights of others (Share fondacija, 2017: 51).

The Press Council analysed the practice of 70 online media in the area of users' comments and republishing others' media content. The conclusion was as follows: "The online media are under constant pressure from competition and finance and many of them do not have the resources to fully control users' comments and republishing content by other media. These processes need to be aligned with their capabilities, and one of the crucial things is to have clear and unambiguous rules that are immediately visible and accessible" (The Press Council, 2018: 14). In line with its role, the Press Council has offered general models of these rules in the publication on its website (The Press Council, 2018: 15-26).

In addition, the Online Media Association has been considerably active in this area. Back in 2015 when it was founded, its (now former) president, Predrag Blagojević, stated that the ethical rules of online journalism were an important issue that this Association wished to address (Mihajlov Prokopović, 2016: 192). Four years after it was founded, the Association is still on this path. This Association issued two documents on this matter: The Online Media Association Code (2017) and The Online Media Copyright Guide (2016).

\section{Conclusion}

Our analysis of the solutions offered by European and Serbian regulations in the field of online media showed that:

1) European documents have adopted a new notion of media that is now gaining broader meaning than before. The criteria of this new notion are elaborated in European policy documents. Editorial control and the purpose of the media have become the main criteria of demarcation between media and digital communication entities that are not media. This is governed by Recommendation CM / REC (2011) 7 of the Committee of Ministers to member states on a new notion of the media.

2) The Audiovisual Media Services Directive (AVMSD) is an important document in European media policy in the field of audiovisual media and digital media,

11 The Press Council (2016).Guidelines for the implementation of Serbian Journalists' Code of Ethics in the Online Environment, The Press Council, Belgrade, 2016. 
which introduced the principles of technological neutrality and gradual regulation.

3) In Serbia, online media and the new opportunities that digital technology provides to traditional media became the subject matter of broader legal regulation in 2014 (by enacting the Public Information and Media Act, and the Eelectronic Media Act). However, it has been estimated that these laws did not meet new challenges but dealt with topics from the past (Milivojević, 2017: 164).

4) In the field of ethical and professional rules of journalism, self-regulatory mechanisms provide first results. Guidelines for the implementation of Journalists' Code of Ethics of Serbia in the online environment, adopted in 2016, regulate some of the current issues of online journalism. The Online Media Association issued two documents in this area: the Online Media Association's Code (2017) and the Online Media Copyright Guide (2016).

5) The challenges that the online media sphere brings to both online media and citizens have been identified. The major challenges are in the field of privacy and the fabrication of fake news for which digital technology offers highly advanced digital tools.

\section{Literature}

Díaz-Campo, J., \& Segado-Boj, F. (2015). Journalism ethics in a digital environment: How journalistic codes of ethics have been adapted to the Internet and ICTs in countries around the world. Telematics and Informatics. 32 (4). 735-744.

Direct Media United Solutions. (2019). Media trends 2019. Accessed 29.9.2019. https://directmedia.biz/wp-content/uploads/pdf/Media_Trends_2019.pdf

Herman, E. S. \& Mekčesni, R. V. (2004): Globalni mediji (The Global Media). Beograd: Clio.

Hermida, A. (2011). Mechanism of Participations: How audience options shape the conversation. U: Singer, J. B. et al. (Prir.). Participatory Journalism: Guarding Open Gates at Online Newspapers. Boston: Wiley-Blackwell. 13-33.

Hermida, A. (2014). Twitter as an Ambient News Network. U: Weller, K., Bruns, A., Burgess, J., Mahrt, M. \& Puschmann, C. (Prir.). Twitter and Society. New York: Peter Lang Publishing. pp.359-373.

IREX (2018). Media Sustainability Index 2018: Europe \& Eurasia, Accessed: 14.9.2019; https://www.irex.org/sites/default/files/pdf/media-sustainabilityindex-europe-eurasia-2018-full.pdf 
IREX (2019). Media Sustainability Index 2019: Europe \& Eurasia, Accessed: 14.9.2019; https://www.irex.org/sites/default/files/pdf/media-sustainabilityindex-europe-eurasia-2019-full.pdf

Jakubowicz, K. (2009). A new notion of media? The First COE Conference of Ministers responsible for Media and New Communication Services, 28-29 May 2009, Reykjavik: Council of Europe.

Kastels, M. (2014). Moć komunikacija (The Power of Communications). Beograd: Clio.

Lorimer, R. (1998). Masovne komunikacije (Mass Communications). Beograd: Clio.

Martinoli, A. Krivokapić, N. Perkov, B. Stojković, M. (2019). Regulatorni okvir i poslovni modeli onlajn medija: priručnik (The Regulatory Framework and Business Models of Online Media: A Handbook). Beograd: Fondacija za otvoreno društvo.

Mihajlov Prokopović, A. (2016). Transformacija tradicionalnih medija u novom tehnološkom okruženju (Transformation of Traditional media in a New Technological Environment), Doktorska disertacija, Univerzitet u Beogradu: Fakultet političkih nauka.

Mihajlov Prokopović, A. and Jevtović, Z. (2017). Transformaton of traditional media in Serbia to the networked society. U: Pralica, D. i Šinković, N. (Prir.). Digitalne medijske tehnologije i društveno-obrazovne promene 7 (136-148). Novi Sad: Filozofski fakultet.

Milić, D. (2016). Vodič kroz autorsko pravo za onlajn medije (Online Media Copyright Guide). Niš: Asocijacija onlajn medija.

Milivojević, S. ( 2017). Šta je novo u novim medijima? (What's New in the New Media)? Reč. 87/33. pp.159-172.

Milutinović, I. (2018). Protivrečnosti evropske medijske politike (The Contradictions of European Media Policy) CM: Communication and media. XIII(42). pp.105-132.

Oxford Research Encyclopedia of Communication (2018). Fake News. Oxford: Oxford University Press.

Savet za štampu. (2018). Analiza primene Smernica za primenu Kodeksa novinara Srbije u onlajn okruženju u 70 medija (Analysis of the application of Guidelines for the implementation of the Serbian Journalist' Code of Ethics in online environment in 70 media). Beograd: Fondacija za otvoreno društvo, Srbija.

Share fondacija. (2017). Share@Work2016 - monitoring digitalnih prava i sloboda u Srbiji (Share @Work 2016 - Monitoring digital rights and freedom in Serbia). 
Silverman, C. and Alexander, L. (2016). How Teens In The Balkans Are Duping Trump Supporters With Fake News. BuzzfeedNews, 3 November 2016. (Accessed 29.9.2019); https://www.buzzfeednews.com/article/craigsilverman/how-macedonia-became-a-global-hub-for-pro-trump-misinfo

Singer, J. (2011). Taking Responsibility: Legal and ethical issues in participatory journalism. U: Singer, J. B. et al. (Prir.). Participatory Journalism: Guarding Open Gates at Online Newspapers. Boston: Wiley-Blackwell. pp.121-139.

Smernice za primenu Kodeksa novinara Srbije u onlajn okruženju (Guidelines for the implementation of the Journalist' Code of Ethics of Serbia in the online environment). Savet za štampu, Beograd, 2016.

Statistical Office of the Republic of Serbia. (2019). Usage of information and communication technologies in the Republic of Serbia, 2019. Belgrade; Available in English at: https://publikacije.stat.gov.rs/G2019/PdfE/G201916014.pdf

Statistical Office of the Republic of Serbia. (2018). Usage of information and communication technologies in the Republic of Serbia, 2018. Belgrade. Available in English at: https://publikacije.stat.gov.rs/G2018/PdfE/G201816013.pdf

Strategija razvoja sistema javnog informisanja u Republici Srbiji do 2016. godine (Strategy for the Development of the Public Information System in the Republic of Serbia until 2016), Službeni glasnik Republike Srbije, br. 75/2011. available at: http://www.pravno-informacioni-sistem.rs/SlGlasnikPortal/eli/rep/sgrs/ vlada/strategija/2011/75/1/reg

Stojković, M. (2017). Kodeks Asocijacije onlajn medija (Online Media Association's Code). Niš: Asocijacija onlajn medija

Legal acts

Directive 2010/13/EU of the European Parliament and of the Council of 10 March 2010 on the coordination of certain provisions laid down by law, regulation or administrative action in Member States concerning the provision of audiovisual media services (Audiovisual Media Services Directive). Available in English at: https:// eur-lex.europa.eu/legal-content/EN/ALL/?uri=CELEX:32010L0013 (Accessed: 14.9.2019).

Recommendation CM / REC (2011) 7 of the Committee of Ministers to member states on a new notion of the media. Adopted by the Committee of Ministers on 21 September 2011 at the 1121st meeting of the Ministers' Deputies. Accessed 15.9.2019. https://www.osce.org/odihr/101403?download=true

Zakon o elektronskim medijima (Electronic Media Act), Službeni glasnik R. Srbije br. 83/2014. 
Zakon o javnom informisanju (Public information Act), Službeni glasnik R. Srbije br. $43 / 2003$.

Zakon o javnom informisanju i medijima (Public Information and Media Act), Službeni glasnik RS br. 83/2014.

\author{
Др Анка Михајлов Прокоповић, \\ Доценткиња, Департман за комуникологију и новинарство, \\ Филозофског факултета Универзитета у Нишу \\ Др Марија Вујовић, \\ Доценткиња, Департман за комуникологију и новинарство, \\ Филозофског факултета Универзитета у Нишу
}

\title{
МЕДИЈИ У ДИГИТАЛНОМ ДОБУ: РЕГУЛАТОРНИ АСПЕКТИ
}

\section{Резиме}

Велики утицај дигиталне технологије довео је до преиспитивања концепта медија. У раду се испитују изазови који су у области регулације медија настали са развојем дигиталне медијске сфере. У првом делу рада се ти изазови идентификују, а потом се анализирају решења која су примењена у области европске и српске регулативе. Указује се на то да је нови концепт медија „проширен” у дигиталном добу и да га сада чине нови медијски субјекти, нове форме и нове медијске активности. Ипак, колико год промењено то ново поимање медија и даље се може разграничити у односу на субјекте комуникативне праксе у дигиталном окружењу који то нису. Differentia specifica коју уводи европска регулатива је уређивачка контрола и сврха медија. Анализирана је регулатива у Србији, која Законом о јавном информисању и медијима прописује обавезу интернет страница које желе да буду медији да се пријаве у Регистар медија. Онлајн медији су ово прихватили, вероватно и зато што је то услов за учествовање на конкурсима за суфинансирање јавног интереса у медијима. Саморегулаторни механизми у области онлајн медија анализирани су са посебним освртом на ситуацију у Србији где су 2016. године усвојене Смернице за примену Кодекса новинара Србије у онлајн окружењу.

Кључне речи: медијска регулатива, онлајн медији, интернет, саморегулација. 